\title{
Trpc6 inactivation confers protection in a model of severe nephrosis in rats
}

\author{
Eun Young Kim ${ }^{1} \cdot$ Parisa Yazdizadeh Shotorbani ${ }^{1} \cdot$ Stuart E. Dryer ${ }^{1,2}$ (1) \\ Received: 19 January 2018 / Revised: 25 April 2018 / Accepted: 7 May 2018 / Published online: 22 May 2018 \\ (C) The Author(s) 2018
}

\begin{abstract}
Mutations in canonical transient receptor potential-6 (TRPC6) channels give rise to rare familial forms of focal and segmental glomerulosclerosis (FSGS). Here we examined a possible role for TRPC6 in the progression of chronic puromycin aminonucleoside (PAN) nephrosis in Sprague-Dawley rats, a classic model of acquired nephrotic syndromes. We used CRISPR/Cas9 technology to delete a 239-bp region within exon 2 of the $\operatorname{Trp} c 6$ gene (Trpc $6^{\mathrm{del}}$ allele). Trpc ${ }^{\mathrm{del} / \mathrm{del}}$ rats expressed detectable Trpc 6 transcripts missing exon 2, and TRPC6 proteins could be detected by immunoblot of renal cortex. However, the abundance of Trpc 6 transcripts and TRPC6 protein in renal cortex was much lower than in $\operatorname{Trp} \sigma^{\mathrm{wt} / \mathrm{wt}}$ littermates, and functional TRPC6 channels could not be detected in whole-cell recordings from glomerular cells cultured from Trpc $6^{\mathrm{del} / \mathrm{del}}$ animals, possibly because of disruption of ankyrin repeats 1 and 2. During the chronic phase of PAN nephrosis, $\operatorname{Tr} p c 6^{\mathrm{del} / \mathrm{del}}$ rats had reduced urine albumin excretion, reduced serum cholesterol and triglycerides, and improved azotemia compared to wild-type $\operatorname{Trp} c 6^{\mathrm{wt} / \mathrm{wt}}$ littermates. Glomerulosclerosis was severe during chronic PAN nephrosis in $\operatorname{Trp} c 6^{\mathrm{wt} / \mathrm{wt}}$ rats but was markedly reduced in $\operatorname{Trp} c 6^{\mathrm{del} / \mathrm{del}}$ littermates. Trpc $6^{\mathrm{del} / \mathrm{del}}$ animals also had less severe tubulointerstitial fibrosis as assessed by several biochemical and histological analyses, as well as reduced foot process effacement and glomerular basement thickening compared to Trpc $6^{\mathrm{wt} t / \mathrm{wt}}$ controls. None of the manipulations in this study affected the abundance of TRPC5 channels in renal cortex. TRPC 3 was increased in PAN nephrosis and in $\operatorname{Trpc} 6^{\mathrm{del} / \mathrm{del}}$ rats. These data support a role for TRPC6 channels in driving an acquired form of secondary FSGS.
\end{abstract}

\section{Key messages}

- We examined aminonucleoside nephrosis in rats with wild type and inactivated TRPC6.

- TRPC6 channels were inactivated by CRISPR/Cas9 editing of the Trpc6 gene.

- TRPC6 inactivation reduced albuminuria in the chronic but not the acute phase.

- TRPC6 inactivation reduced glomerulosclerosis and ultrastructural changes.

- TRPC6 inactivation also reduced interstitial changes and renal fibrosis.

Keywords Chronic kidney disease · TRPC6 · FSGS · Glomerulosclerosis

Electronic supplementary material The online version of this article (https://doi.org/10.1007/s00109-018-1648-3) contains supplementary material, which is available to authorized users.

Stuart E. Dryer

sdryer@uh.edu

1 Department of Biology and Biochemistry, University of Houston, Houston, TX, USA

2 Department of Medicine, Division of Nephrology, Baylor College of Medicine, Houston, TX, USA

\section{Introduction}

Focal and segmental glomerulosclerosis (FSGS) occurs following a sufficient loss of podocytes [1,2], often secondary to other pathological states [3]. A primary form of FSGS occurs as a result of circulating factors that drive glomerular dysfunction through poorly understood mechanisms $[4,5]$. In addition, genetic studies have identified gain-of-function mutations in the Trpc6 gene in patients with familial FSGS 
[6-10]. Trpc6 encodes a widely expressed $\mathrm{Ca}^{2+}$-permeable channel (TRPC6) found in mesangial cells, podocytes, and other cells [11].

Familial FSGS associated with Trpc6 mutations is rare [10], and it is not known if dysregulation of wild-type TRPC6 channels contributes to acquired FSGS. Patients with non-familial glomerular diseases, including primary FSGS, express TRPC6 at higher levels within glomeruli [12]. It is not known if this plays a role in driving the disease progression or, alternatively, if TRPC6 upregulation is a compensatory mechanism or a non-specific downstream marker of disease processes. We have recently shown that podocyte TRPC6 dysregulation can be driven by circulating factors present in patients with primary FSGS [13].

Previous studies have attempted to determine if TRPC6 contributes to kidney dysfunction and glomerulosclerosis using genetic manipulations of TRPC6 in mice [14, 15]. However, the manipulations that were used to produce FSGS-like lesions in those studies constrain conclusions that can be drawn since the kidney disease was transient and mild, even in $\operatorname{Trp} c \sigma^{+/+}$controls [14] or entailed genetic manipulations that cause artificial sustained TRPC6 activation $[15,16]$. Beyond considerations of earlier experimental designs, there is value in addressing disease mechanisms in multiple species [17].

Here we have examined if TRPC6 channels play a role in the progression of chronic puromycin aminonucleoside (PAN) nephrosis in rats, an extensively studied model of severe secondary FSGS [1]. Because of its severity, this model more closely resembles patterns seen in human glomerular diseases than mouse models used to date. It does not require additional manipulations that artificially sustain TRPC6 activation. We also used CRISPR/Cas9 genome editing to delete a 239-bp region within exon 2 of Trpc6, which introduced numerous stop codons downstream of the deletion. Truncated Trpc6 transcripts and TRPC6 proteins could still be detected, possibly as a result of posttranscriptional skipping of exon 2 [18, 19]. However, TRPC6 abundance was much lower in renal cortex of $\operatorname{Trpc} \sigma^{\mathrm{del} / \mathrm{del}}$ rats, and we were unable to detect functional TRPC6 channels in glomerular cells cultured from those animals. Consequently, it was still possible to test the central hypothesis of this study.

\section{Material and methods}

\section{Genome editing procedures}

$\operatorname{Trpc} 6^{\mathrm{del} / \mathrm{del}}$ rats were generated using CRISPR/Cas9 technology through a contract with a commercial vendor (Transposagen Biopharmaceuticals Inc.). The guide RNAs targeted a 239-bp domain in exon 2 of the rat Trpc6 gene. The sequences of the two CRISPR guide RNAs used were as follows:

\subsection{GGAAGAAGGTTGGCTAATCG \\ 2.2 GGAAAACTTGTCTCGAGTTG}

These guide RNAs were designed to be specific for Trpc6 and do not target genes encoding closely related channel proteins (see Supplemental Material). It is important to note that we cannot entirely exclude that they may have off-target effects elsewhere. Littermates bred from $\operatorname{Trp} c 6^{\mathrm{wt} / \mathrm{del}}$ heterozygotes were genotyped using PCR primers that span the deleted region of the Trpc6 gene (primer sequences are in Supplemental Material Table 1). RT-PCR analyses of total RNA extracted from renal cortex of $\operatorname{Tr} p c \sigma^{\mathrm{wt} / \mathrm{wt}}$ and $\operatorname{Tr} p c \sigma^{\mathrm{del} /}$ ${ }^{\text {del }}$ rats was carried out using primers designed to span various portions of the Trpc6 transcript, including exons $1-2$, exons $2-4$, exons $4-8$, and exons $8-13$. We also used a primer pair that spanned a short region on either side of the deleted region (exon 1- $\Delta 2$ ) and a primer pair to detect Actb.

\section{Glomerular cell isolation and electrophysiology}

Decapsulated glomeruli were isolated from $\operatorname{Trpc} \sigma^{\mathrm{wt} / \mathrm{wt}}$ and $\operatorname{Trpc} 6^{\mathrm{del} / \mathrm{del}}$ rats [20]. Epithelial cells that grew out of the glomeruli after 2 days were re-plated onto collagen-coated glass coverslips and used for electrophysiology as described previously [13, 21]. Data are from cells isolated from at least three animals in each group. Recordings were made with an Axopatch 1D amplifier (Molecular Devices) and analyzed using PClamp ${ }^{\mathrm{TM}} \mathrm{v} 10$ software (Molecular Devices). The bath solution contained $150 \mathrm{mM} \mathrm{NaCl}, 5.4 \mathrm{mM} \mathrm{CsCl}, 0.8 \mathrm{mM}$ $\mathrm{MgCl}_{2}, 5.4 \mathrm{mM} \mathrm{CaCl}_{2}$, and $10 \mathrm{mM}$ HEPES, pH 7.4 at $1.5 \mathrm{ml} / \mathrm{min}$. Pipette solutions in all experiments contained $10 \mathrm{mM} \mathrm{NaCl}, 125 \mathrm{mM} \mathrm{CsCl}, 6.2 \mathrm{mM} \mathrm{MgCl}, 10 \mathrm{mM}$ HEPES, and $10 \mathrm{~mm}$ EGTA, pH 7.2. Briefly, after making intracellular contact, cells were held at $-40 \mathrm{mV}$. Currents were periodically monitored during application of voltage ramps ( -80 to $+80 \mathrm{mV}$ over $2.5 \mathrm{~s}$ ), before and after application of $100 \mu \mathrm{M}$ ATP by gravity-fed superfusion. We have previously shown that ATP activates TRPC6 channels in podocytes through actions on $\mathrm{G}$ protein-coupled P2Y receptors [21]. ATP-evoked currents occurred within 60-90 s after switching bath solutions, corresponding to the dead time of the perfusion system and chamber. ATPevoked currents were blocked by $100 \mathrm{nM}$ SAR-7334 (MedChem Express), a highly specific inhibitor of TRPC6 [22]. Currents were quantified at $+80 \mathrm{mV}$ and are presented as the fold change in presence of ATP over baseline. We also analyzed the percentage of cells with discernible increases in current evoked by ATP in the two groups. 


\section{Chronic PAN nephrosis}

These protocols were approved by the University of Houston Institutional Animal Care and Use Committee following NIH guidelines. $\operatorname{Trpc} \sigma^{\mathrm{wt} / \mathrm{wt}}$ rats and $\operatorname{Tr} p c \sigma^{\mathrm{del} / \mathrm{del}}$ littermates (100$150 \mathrm{~g}$ ) were given two injections of PAN (Sigma-Aldrich) dissolved in $0.9 \%$ sterile saline. A first injection of $200 \mathrm{mg} /$ $\mathrm{kg}$ i.p. was followed by a second injection of $100 \mathrm{mg} / \mathrm{kg}$ i.p. administered 30 days later. Controls received the saline vehicle at the same times. Urine albumin was measured using a commercial ELISA assay (Exocell Inc.). Mean arterial blood pressure was measured between by tail-cuff plethysmography (CODA 6, Kent Scientific). At 30 days after the second injection, blood was sampled and animals were sacrificed by $\mathrm{CO}_{2}$ inhalation followed by cervical dislocation and the kidneys and heart were excised and weighed. A portion of renal cortex of one kidney was removed and reserved for biochemical, histological, and ultrastructural analysis.

\section{Immunoblot analysis}

These methods were described previously [13]. Renal cortex was homogenized in M-PER ${ }^{\mathrm{TM}}$ mammalian protein extraction buffer (Thermo Fisher Scientific) and sonicated on ice. The homogenates were subjected to centrifugation at 13,000 rpm for $30 \mathrm{~min}$. Protein concentrations of the supernatants were determined with Bradford reagent (Bio-Rad). Rabbit antibodies against TRPC6 (ACC-017) and TRPC3 (ACC-016) were from Alomone Labs. The TRPC6 antibody targets motifs encoded by exon 1 located in the amino-terminal and upstream of the deletion in the $\operatorname{Trpc} \sigma^{\mathrm{del}}$ allele. We also used a polyclonal TRPC6 antibody from Booster Biological Technology that targets residues 248-264 in the rat channel, downstream of the deletion. A mouse monoclonal antibody against TRPC5 was from NeuroMAB. We also used a rabbit polyclonal antibody against TRPC5 from Alomone (ACC020). All TRPC antibodies were used at a dilution of 1:1000. A mouse monoclonal antibody (clone 1A4) against $\alpha$-smooth muscle actin (SMA) was from Sigma-Aldrich.

\section{Histology and ultrastructure}

Portions of kidney were immersion-fixed, embedded in paraffin, and 3- $\mu \mathrm{m}$ serial sections staining by periodic acid-Schiff's (PAS) and Masson's trichrome methods and by immunohistochemistry. All pathological specimens were evaluated by an observer blind to the nature of the treatment group. For each animal, the glomerular score (GS) in PAS-stained sections was graded using a scale of $0-4: 0$ was assigned to normal glomeruli, 1 denoted glomeruli with mesangial expansion, 2 denoted glomeruli in which sclerosis encompassed less than $50 \%$ of the glomerulus, 3 denoted glomeruli with lesions encompassing $50-75 \%$ of the glomerulus, and 4 denoted glomeruli with lesions encompassing more than $75 \%$ of the glomerulus or fully collapsed glomeruli. GS was evaluated in 25-50 glomeruli and averaged to obtain a mean value for each animal. Statistical analysis was carried out on the mean values from each group of animals, with $N=6$ rats per group. Immunohistochemistry for the rat macrophage marker CD68 was carried out by $\mathrm{ABC}$ method using a monoclonal primary antibody against rat CD68 (ED-1) from Abcam (ab31630) at a dilution of 1:200. The average number of stained cells per glomerulus for each animal was determined by an observer blind to the treatment group. A portion of renal cortex was fixed by immersion in 3\% glutaraldehyde plus 3\% paraformaldehyde in $0.1 \mathrm{M}$ sodium cacodylate buffer $\mathrm{pH} 7.3$ for ultrastructural analysis as described in detail previously [23]. The thickness of the glomerular basement membrane was determined from these images. Podocyte foot process width (FPW) was calculated as FPW $=\pi / 4 \times \sum$ GBM length $/ \sum$ foot process where $\Sigma$ GBM length is the total GBM length measured in each picture and $\sum$ foot process is the total number of foot processes counted in each picture. The term $\pi / 4$ corrects for random variation in the angle of section relative to the long axis of the podocyte [24].

\section{Statistical analyses}

All statistical analyses were carried out using public-access computational tools (http://www.vassarstats.net) with $P<0$. 05 regarded as significant. Immunoblot assays were performed in triplicate and analyzed by densitometry. The data are presented as fold changes relative to the lowest value observed in a control group and are presented as mean \pm SD. They were analyzed by Student's unpaired or Bonferroni's $t$ test. Electrophysiological data were analyzed by Mann-Whitney $U$ test and by Fisher's exact test. Data on 24-h urine albumin excretion and other quantitative measures of renal and metabolic status are presented as mean \pm SEM and as scatter plots from $N=6$ rats per group. Data were analyzed by two-way ANOVA followed by Tukey's honest significant difference post hoc test The two independent variables were genotype $\left(\operatorname{Trp} c \sigma^{\mathrm{wt} / \mathrm{wt}}\right.$ vs. $\left.\operatorname{Trp} c \sigma^{\mathrm{del} / \mathrm{del}}\right)$ and drug treatment (PAN vs. saline vehicle). A statistically positive result was inferred when $F$ values for the interaction between drug effects and genotype indicated $P<0.05$.

\section{Results}

\section{Effects of the exon 2 deletion on renal cortical TRPC6 expression and function in glomerular cells}

The strategy used to generate $\operatorname{Trpc} 6$ exon 2 deletions in rats is summarized in Fig. 1a. The deletion of a 239-bp region within the Trpc6 gene was confirmed by genomic sequencing and 

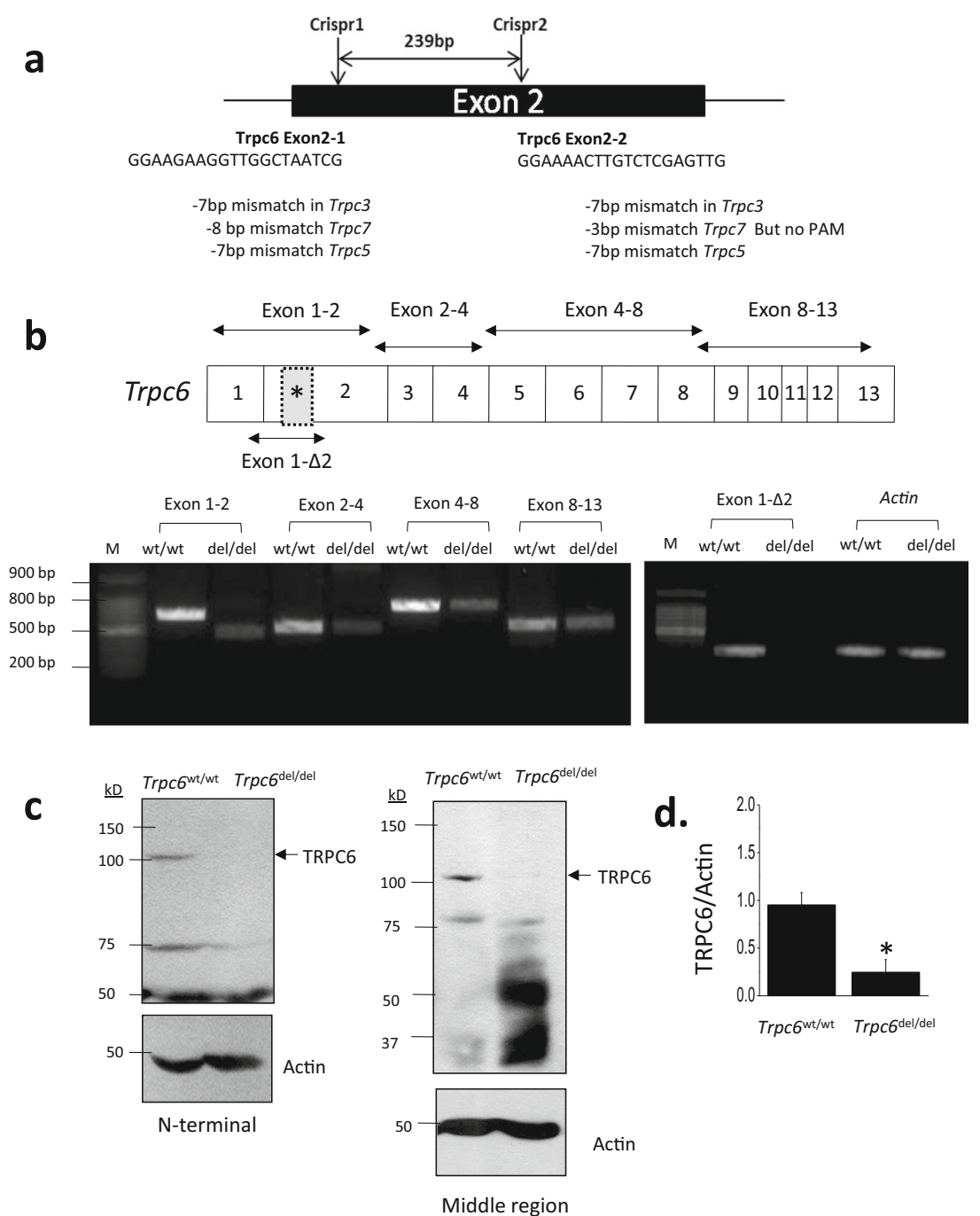

Fig. 1 Generation of the $\operatorname{Trpc} \sigma^{\mathrm{del}}$ allele and its expression in $\operatorname{Tr} p c \sigma^{\mathrm{del} / \mathrm{del}}$ and $\operatorname{Trpc} \sigma^{\mathrm{wt} / \mathrm{wt}}$ rats. a Schematic showing CRISPR/Cas9 strategy used to generate rats with a 239-bp deletion in the second exon of Trpc6. We initially expected this deletion to result in numerous frameshift mutations downstream of the deletion. The sequences of guide RNAs used to generate the animals are also shown. b Conventional RT-PCR of Trpc6 transcripts in renal cortex using primer pairs that span different portions of the transcript. All of the primer pairs produced robust signal from renal cortex of $\operatorname{Trpc} \sigma^{\mathrm{wt} / \mathrm{wt}}$ rats, but signal from all primer pairs was reduced in $\operatorname{Trpc} \sigma^{\mathrm{del} / \mathrm{del}}$ littermates and was missing using the primer pair $(1-\Delta 2)$ that

was readily seen in PCR analyses of genomic DNA used to genotype the animals. This deletion introduced numerous premature stop codons downstream of the deletion. However, we were able to detect Trpc6 transcripts in renal cortex by RTPCR using four different primer pairs, although these transcripts were present at substantially lower levels in $\operatorname{Tr} p c \sigma^{\mathrm{del} /}$ del rats compared to $\operatorname{Trpc} 6^{\mathrm{wt} / \mathrm{wt}}$ littermates (Fig. 1b). By contrast, when we used a primer pair that targeted regions of the transcript very close to the deleted region within exon 2 (exon $1 \Delta 2)$, we obtained signals of the appropriate size in $\operatorname{Trpc} 6^{\mathrm{wt} / \mathrm{wt}}$ rats but not in $\operatorname{Trpc} \sigma^{\text {del/del }}$ littermates (Fig. 1b). We also observed TRPC6 subunits in immunoblot analysis of renal targets residues very close to the deleted region. c Example of immunoblot analysis of TRPC6 in renal cortical extracts from a $\operatorname{Trpc} 6^{\mathrm{wt} / \mathrm{wt}}$ and a $\operatorname{Trpc} 6^{\mathrm{del} / \mathrm{del}}$ rat as indicated. The blot to the left showed signal obtained using an antibody targeting motifs upstream of the deletion, and the blot to the right was obtained using a different antibody targeting a sequence downstream of the deletion. Signal from $\operatorname{Trpc} 6^{\mathrm{wt} / \mathrm{wt}}$ rats was easy to see but was extremely faint in the $\operatorname{Trp} c \sigma^{\mathrm{del} / \mathrm{del}}$ animals. d Densitometric analysis of the signal obtained using the Nterminal antibody with $N=6$ animals per group

cortex of $\operatorname{Tr} p c 6^{\mathrm{wt} / \mathrm{wt}}$ and $\operatorname{Tr} p c 6^{\mathrm{del} / \mathrm{del}}$ rats, although the signal from $\operatorname{Trp} c 6^{\mathrm{del} / \mathrm{del}}$ rats was very faint (Fig. 1c, d). This pattern was seen with two different commercial polyclonal antibodies that target different epitopes within the TRPC6 channel. Thus, $\operatorname{Trpc} 6^{\mathrm{del} / \mathrm{del}}$ animals are able to express very low levels of TRPC6 subunits, possibly by splicing out the exon containing premature stop codons, a phenomenon reported by other investigators studying other genes modified by CRISPR/Cas9 methods $[18,19]$. It is clear from the expression levels of transcripts and proteins that the $\operatorname{Trp} c \sigma^{\mathrm{del}}$ is a strongly hypomorphic allele. We confirmed this using whole-cell recordings of glomerular cells cultured from $\operatorname{Trpc} 6^{\mathrm{wt} / \mathrm{wt}}$ and 
$\operatorname{Trpc} 6^{\text {del/del }}$ animals (Fig. 2). We have previously shown that ATP activates TRPC 6 channels in podocytes by activation of P2Y receptors [21]. Here we observed that $100 \mu \mathrm{M}$ ATP caused robust activation of cationic currents in 8 out of 11 cells, in total cultured from three different Trpc $6^{\mathrm{wt} / \mathrm{wt}}$ animals, and cells from all three animals responded to ATP. As we observed previously [21], those currents peaked within 60-90 s after the onset of gravityfed perfusion with external saline containing ATP. The ATP-evoked currents were blocked completely by subsequent application of $100 \mathrm{nM}$ SAR-7334, a selective inhibitor of TRPC6 [22] (Fig. 2a). By contrast, $100 \mu \mathrm{M}$ ATP did not activate cationic currents in any of ten cells examined from three different $\operatorname{Tr} p c 6^{\mathrm{del} / \mathrm{del}}$ rats $(P<0.0007$ by Mann-Whitney $U$ test analysis of fold increases in current and $P<0.0008$ by Fisher's exact test of the numbers of cells with a discernible response).

\section{Urine albumin excretion and renal function}

PAN-evoked nephrosis in rats occurs in two phases $[1,25$, 26]. An acute injury phase characterized by severe proteinuria occurs within days after a single PAN injection. At that time, no lesions can be seen by light microscopy. This recovers over the next 2-3 weeks but is followed by a sustained reemergence of albuminuria that, while less severe, is accompanied by glomerulosclerosis $[1,25,26]$. The chronic phase of this model is relevant to human nephrotic syndromes. We
Fig. 2 Whole-cell recordings from glomerular cells cultured from $\operatorname{Trp} c \sigma^{\mathrm{wt} / \mathrm{wt}}$ and $\operatorname{Trp} c \sigma^{\mathrm{del} / \mathrm{del}}$ rats. Representative traces of recordings showing currents before and after application of $100 \mu \mathrm{M}$ ATP. Note increase in current in cells from $\operatorname{Trpc} 6^{\mathrm{wt} / \mathrm{wt}}$ rats, and blockade of this currents by $100 \mathrm{~nm}$ SAR-7334, a selective blocker of TRPC6 (a). Note also that cells cultured from $\operatorname{Trpc} \sigma^{\mathrm{del} /}$

${ }^{\text {del }}$ rats did not respond to ATP (b).

Bar graph in (c) shows mean fold increase in current evoked by ATP relative to baseline in cells from $\operatorname{Trp} c \sigma^{\mathrm{wt} / \mathrm{wt}}$ and $\operatorname{Tr} p c \sigma^{\mathrm{del} / \mathrm{del}}$ rats. Error bars represent SEM. Numbers above bars indicate number of cells that respond to ATP over the total number of cells recorded. Data were highly statistically significant by MannWhitney $U$ test and Fisher's exact test for proportions

\section{a}

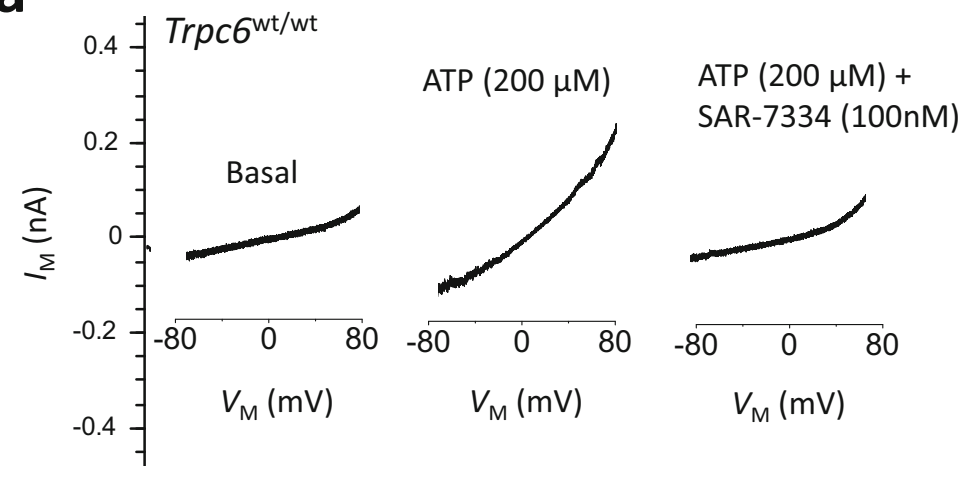

b
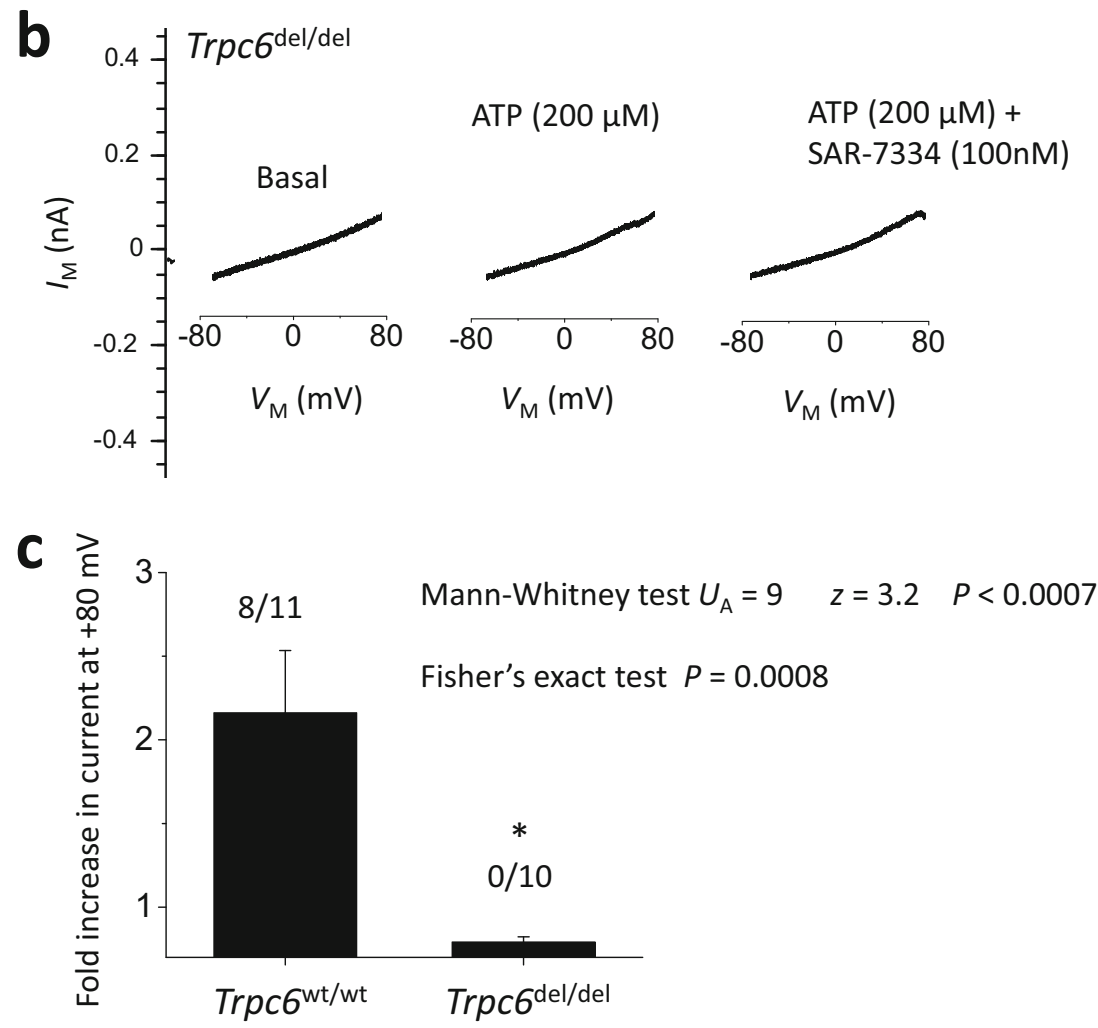
observed no difference in 24-h urine albumin excretion in PAN-treated $\operatorname{Tr} p c \sigma^{\mathrm{wt} / \mathrm{wt}}$ and $\operatorname{Trp} c \sigma^{\mathrm{del} / \mathrm{del}}$ rats during the acute phase, measured 10 days after the initial PAN injection (Fig. 3a). At that time, all PAN-treated animals exhibited severe proteinuria $>40 \mathrm{mg} / 24 \mathrm{~h}$. There was no difference in albumin excretion between $\operatorname{Tr} p c \sigma^{\mathrm{wt} / \mathrm{wt}}$ and $\operatorname{Tr} p c \sigma^{\mathrm{del} / \mathrm{del}}$ rats that received saline. Two-way ANOVA revealed a

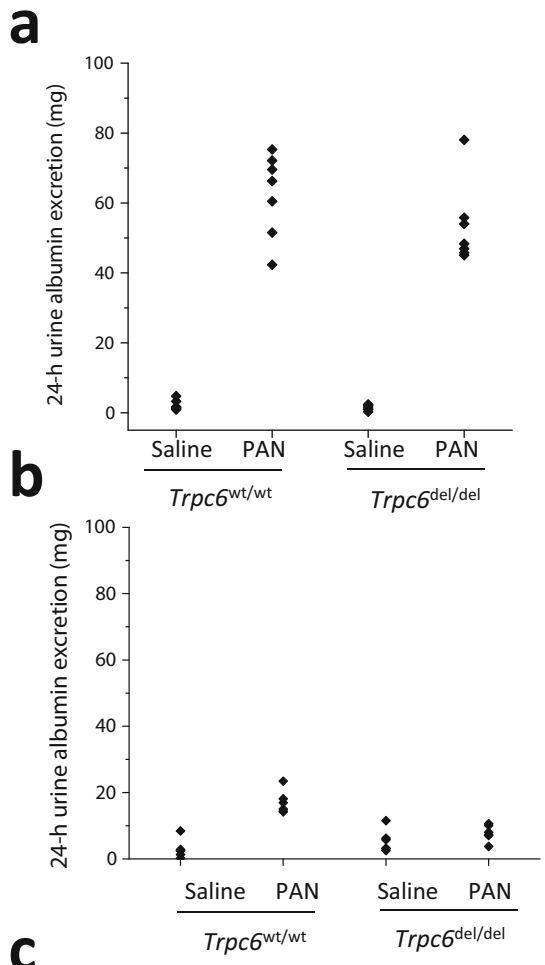

C

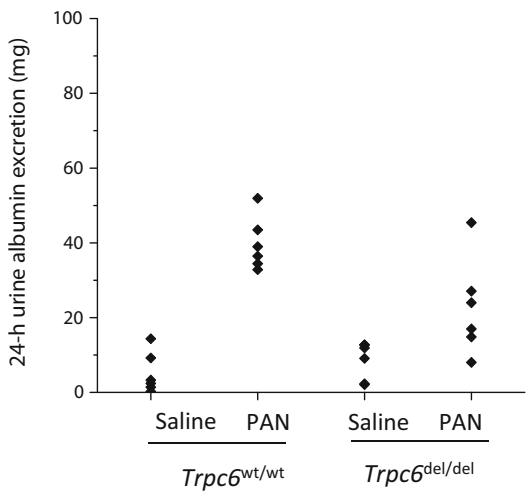

Fig. 3 Reduced albuminuria in chronic PAN nephrosis in $\operatorname{Trp} c 6^{\mathrm{del} / \mathrm{del}}$ rats compared to $\operatorname{Trpc} \sigma^{\mathrm{wt} / \mathrm{wt}}$ littermates. a Urine albumin excretion (over $24 \mathrm{~h}$ ) in rats 10 days after an initial PAN or saline injection, as indicated. Scatter graph on left shows urine albumin excretion from each animal in each group. Bar graph to the right shows mean \pm SEM for the six animals in each group. Two-way ANOVA indicates marked effect of PAN on albumin excretion, but there was no difference in this effect between $\operatorname{Trpc} 6^{\mathrm{wt} / \mathrm{wt}}$ and $\operatorname{Trpc} \sigma^{\mathrm{del} / \mathrm{del}}$ rats, and no interaction between the effects of genotype and drug treatment. b In the same animals, 30 days after the first PAN injection, there is now a statistically robust difference in 24-h urine albumin excretion between $\operatorname{Trpc} 6^{\mathrm{wt} / \mathrm{wt}}$ and $\operatorname{Trp} c 6^{\mathrm{del} / \mathrm{del}}$ animals that received revealed by significant interaction effect between genotype and robust effect of PAN, but no statistically significant interaction between the effects of genotype and PAN treatment at that stage $(P=0.2336)$.

A difference in the amount of 24-h urine albumin excretion in PAN-treated $\operatorname{Trpc} 6^{\mathrm{wt} / \mathrm{wt}}$ and $\operatorname{Trpc} \sigma^{\mathrm{del} / \mathrm{del}}$ rats was observed 30 days after the first PAN injection (Fig. 3b). At that time, PAN-treated Trpc $6^{\mathrm{wt} / \mathrm{wt}}$ rats had a significant
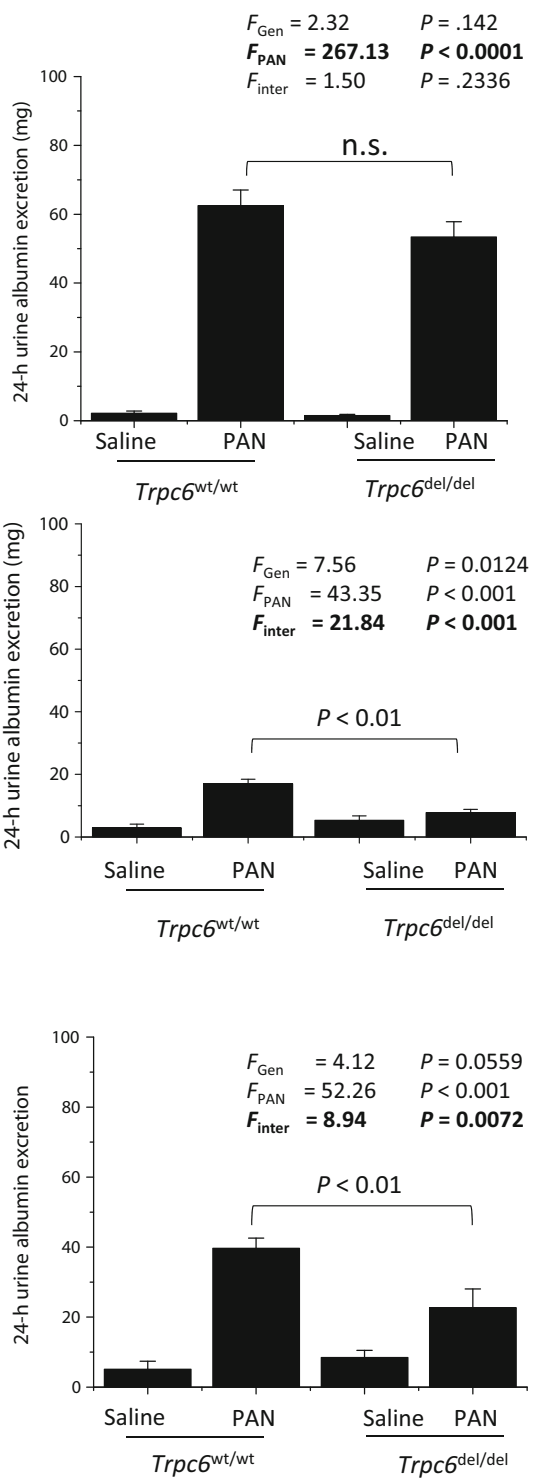

drug treatment and by Tukey's honest significant difference post hoc test. At this stage, $\operatorname{Tr} p c \sigma^{\mathrm{del} / \mathrm{del}}$ animals appear to be completely protected from PAN-evoked albuminuria. A few days after these urine samples were collected, a second injection of PAN or saline was given to these rats. $\mathbf{c}$ Urine albumin excretion in the same animals, 30 days after the second PAN or saline injection (and 60 days after the first one). Urine albumin excretion was increased in PAN-treated animals. There is marked protection from PAN effects in Trpc $6^{\text {del/del }}$ animals. Two-way ANOVA indicates statistically robust interaction between effects of PAN and genotype, and the post hoc test indicates marked difference between $\operatorname{Trpc} 6^{\mathrm{wt} / \mathrm{wt}}$ and $\operatorname{Trpc} 6^{\mathrm{del} / \mathrm{del}}$ rats that received PAN 
increase in 24-h urine albumin excretion compared to saline-treated controls (albeit less than in the acute phase), whereas there was no difference between PAN-treated $\operatorname{Trpc} 6^{\mathrm{del} / \mathrm{del}}$ animals and saline-treated controls. There was a statistically significant interaction between the effects of genotype and PAN treatment $(P<0.001)$ on urine albumin excretion. At that time, the rats were given a second injection of PAN or saline. The protective effect in $\operatorname{Trpc} 6^{\mathrm{del} / \mathrm{del}}$ animals was still observed more than 30 days after the second booster injection (which is 60 days into the disease process), and two-way ANOVA again revealed a robustly significant interaction effect between effects of genotype and PAN treatment on albumin excretion $(P<0.001)$, indicating a partial protective effect of exon 2 deletion (Fig. 3c). Albuminuria at the 60-day time point was not correlated with the degree of proteinuria seen at 10 days (see Supplemental Fig. 1). There was an increase in kidney weight/body weight ratio in PANtreated rats compared to saline-treated controls, but this effect was not changed by Trpc6 knockout (see Supplemental Figs. 2 and 3). PAN treatment and Trpc6 exon 2 deletion had no effect on heart weight or mean arterial pressure (Supplemental Fig. 3).

The protective effect of $\operatorname{Tr} p c \sigma^{\mathrm{del}}$ was observed with several other measurements. PAN-treated rats had increased blood urea nitrogen (BUN) compared to saline-treated controls, measured 60 days after the initial injection. This was less severe in $\operatorname{Tr} p c \sigma^{\mathrm{del} / \mathrm{del}}$ rats compared to $\operatorname{Tr} p c 6^{\mathrm{wt} / \mathrm{wt}}$ littermates, and two-way ANOVA revealed a statistically significant interaction between genotype and PAN treatment on BUN $(P<$ 0.05) (Fig. 4a). Chronic PAN in Trpc6 $6^{\mathrm{wt} / \mathrm{wt}}$ animals caused increases in serum total cholesterol and triglycerides (Fig. 4a), but this was less severe in $\operatorname{Trpc} 6^{\text {del/del }}$ littermates $(P<$ $0.05)$. In a separate experiment with six rats in each group, we measured 24-h urine albumin excretion, BUN, and serum lipids 30 days after injection of PAN or saline (Fig. 4b). In these rats ( $N=6$ per group), we again saw albuminuria and increased BUN in PAN-treated Trpc $6^{\mathrm{wt} / \mathrm{wt}}$ rats but not in PANtreated $\operatorname{Trp} c \sigma^{\mathrm{del} / \mathrm{del}}$ rats, and the protective effect at 30 days was essentially complete $(P<0.05)$ (Fig. $4 b)$.

\section{Histology and ultrastructural analysis}

Animals were sacrificed after completion of the 60-day protocol. Histology assessed by PAS staining was normal in saline-treated $\operatorname{Trp} c \sigma^{\mathrm{wt} / \mathrm{wt}}$ and $\operatorname{Trpc} \sigma^{\mathrm{del} / \mathrm{del}}$ rats (Fig. 5a, b). However, there was marked glomerular scarring and many collapsed glomeruli in all of the PAN-treated $\operatorname{Trp} c 6^{\mathrm{wt} / \mathrm{wt}}$ rats (Fig. 5c). Indeed, virtually, every glomerulus in PAN-treated $\operatorname{Trpc} 6^{\mathrm{wt} / \mathrm{wt}}$ animals exhibited some degree of sclerosis. There was also extensive tubular atrophy, and many tubular protein casts, along with interstitial hypercellularity and fibrosis. The pathology was quantitatively and qualitatively less severe in
PAN-treated $\operatorname{Trp} c 6^{\mathrm{del} / \mathrm{del}}$ rats (Fig. $5 \mathrm{~d}$, e). It was possible to find many unaffected or mildly affected glomeruli in $\operatorname{Trp} c 6^{\mathrm{del} / \mathrm{del}}$ rats. There were indications of tubulointerstitial disease, especially hypercellularity, but hyalinization in tubules was rare in PAN-treated $\operatorname{Trp} c \sigma^{\mathrm{del} / \mathrm{del}}$ rats. A quantitative analysis of glomerulosclerosis in this experiment indicated a significant protective effect of exon 2 deletion (Fig. 5e, right) $\left(P<0.01\right.$ by two-way ANOVA). Trpc $\sigma^{\mathrm{del} / \mathrm{del}}$ rats also had reduced interstitial fibrosis. We detected substantially more $\alpha$ smooth muscle actin (SMA) in the renal cortex of PAN-treated rats than in saline-treated controls. This increase was less severe in $\operatorname{Tr} p c 6^{\mathrm{del} / \mathrm{del}}$ rats compared to $\operatorname{Tr} p c 6^{\mathrm{wt} / \mathrm{wt}}$ littermates (Fig. 6a). This could also be seen in Masson's trichrome staining (Fig. 6). We observed fewer cells expressing the monocyte/macrophage marker CD68 within the glomeruli of PAN-treated $\operatorname{Trp} c 6^{\mathrm{del} / \mathrm{del}}$ rats compared to $\operatorname{Trp} c 6^{\mathrm{wt} / \mathrm{wt}}$ rats (Fig. 7).

Glomerular ultrastructure was indistinguishable in salinetreated $\operatorname{Tr} p c \sigma^{\mathrm{wt} / \mathrm{wt}}$ and $\operatorname{Tr} p c \sigma^{\mathrm{del} / \mathrm{del}}$ rats (Fig. 8). However, ultrastructure was more disrupted in PAN-treated $\operatorname{Tr} p c \sigma^{\mathrm{wt} / \mathrm{wt}}$ animals than $\operatorname{Trp} c 6^{\mathrm{del} / \mathrm{del}}$ littermates, with more extensive foot process effacement and glomerular basement membrane (GBM) thickening. The differences in FPW and GBM thickening in PAN-treated $\operatorname{Tr} p c 6^{\mathrm{wt} / \mathrm{wt}}$ and $\operatorname{Tr} p c 6^{\mathrm{del} / \mathrm{del}}$ animals were quantitatively significant (Fig. 8; see also Supplemental Fig. 4).

\section{Discussion}

TRPC6 channels have been implicated in familial forms of TRPC6, and it has been suggested that these channels also play a role in acquired nephrotic syndromes $[12,13]$. The hypothesis that TRPC6 channels play a role in the progression of acquired FSGS predicts that pathology in chronic PAN nephrosis should be reduced when functional TRPC6 channels are not present. We tested this prediction in $\operatorname{Trp} c 6^{\mathrm{del} / \mathrm{del}}$ Sprague-Dawley rats and their littermate $\operatorname{Tr} p c 6^{\mathrm{wt} / \mathrm{wt}}$ controls generated by CRISPR/Cas9 technology.

The $\operatorname{Trp} c \sigma^{\mathrm{del}}$ allele generated in this study is present at very low levels at both the mRNA and protein level $\operatorname{Trp} c 6^{\mathrm{del} / \mathrm{del}}$ rats, and we were unable to detect functional TRPC6 channels in glomerular cells from those animals, in marked contrast to Trpc $6^{\mathrm{wt} / \mathrm{wt}}$ controls. Nevertheless, the fact that TRPC6 subunits could be detected using two different antibodies, in spite of the fact that the deletion was predicted to induce a shift in the reading frame, indicates precautions that should be taken when using CRISPR/Cas9 technology. Indeed, conclusions of this study must also be tempered by the possibility of offtarget effects of the guide RNAs used here. There are recent examples in which animals have been able to remove disrupted exons, most likely by posttranscriptional splicing processes $[18,19]$ and a similar process could explain why these transcripts and proteins are detectable here. 
Fig. $4 \operatorname{Trpc} 6^{\mathrm{del} / \mathrm{del}}$ rats are protected against changes in blood chemistry seen in chronic PAN nephrosis. a In the same animals shown in Fig. 3 immediately prior to sacrifice, we observed significant reductions in blood urea nitrogen (BUN), total serum cholesterol, and total serum triglycerides in PAN-treated $\operatorname{Trpc} \sigma^{\mathrm{del} / \mathrm{del}}$ animals compared to Trpc $6^{\mathrm{wt} / \mathrm{wt}}$ littermate controls.

Two-way ANOVA showed significant interaction between genotype and drug treatment for all three measures, as well as significant differences between $\operatorname{Trp} c 6^{\mathrm{wt} / \mathrm{wt}}$ and $\operatorname{Trp} c 6^{\mathrm{del} / \mathrm{del}}$ in PAN-treated groups by post hoc test. As with albumin excretion, the protection was not complete. b In a second set of animals $(N=6$ per group), we observed increased 24-h albumin excretion and BUN in PAN-treated $\operatorname{Trp} c \sigma^{\mathrm{wt} / \mathrm{wt}}$ rats but not in $\operatorname{Trp} c \sigma^{\mathrm{del} / \mathrm{del}}$ animals compared to saline-treated controls. Two-way ANOVA showed significant interaction between genotype and drug treatment for both measures, as well as significant differences between $\operatorname{Trp} c \sigma^{\mathrm{wt} / \mathrm{wt}}$ and $\operatorname{Trp} c \sigma^{\mathrm{del} /}$ del in PAN-treated groups by post hoc test. At this earlier time point in PAN nephrosis, protective effect of TRPC6 knockout is essentially complete a
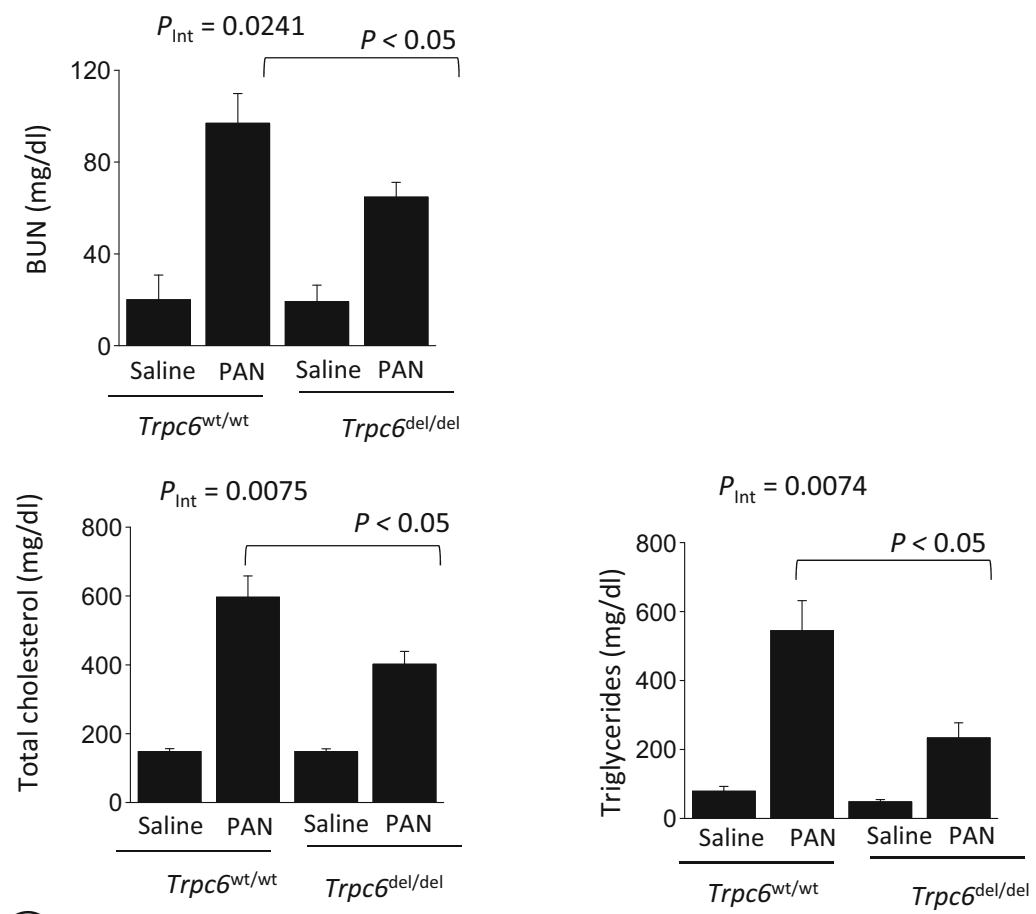

In any case, the TRPC 6 proteins produced in $\operatorname{Trp} c 6^{\mathrm{del} / \mathrm{del}}$ rats are non-functional in glomerular cells. Note that two of the three ankyrin repeats in the $\mathrm{N}$-terminal are missing, resulting in disruption of the entire ankyrin repeat domain. Those ankyrin repeats are conserved in all TRPC channels and are necessary for assembly of channels into functional tetramers [27-29]. As an aside, we should note that macroscopic currents through wild-type TRPC6 channels in podocytes $[14,20,30]$ do not exhibit dual rectification (at both negative and positive membrane potentials) that is often seen with TRPC6 channels examined in heterologous expression systems such as HEK293 cells [31]. However, dual rectification is not always seen even with heterologously expressed TRPC6 channels $[32,33]$. This is by no means unique to podocytes and has been seen in TRPC6 currents in several other preparations [34-38]. The biophysical and biochemical bases for the complex rectifications that are sometimes seen with TRPC6 channels is not known, but it bears noting that 

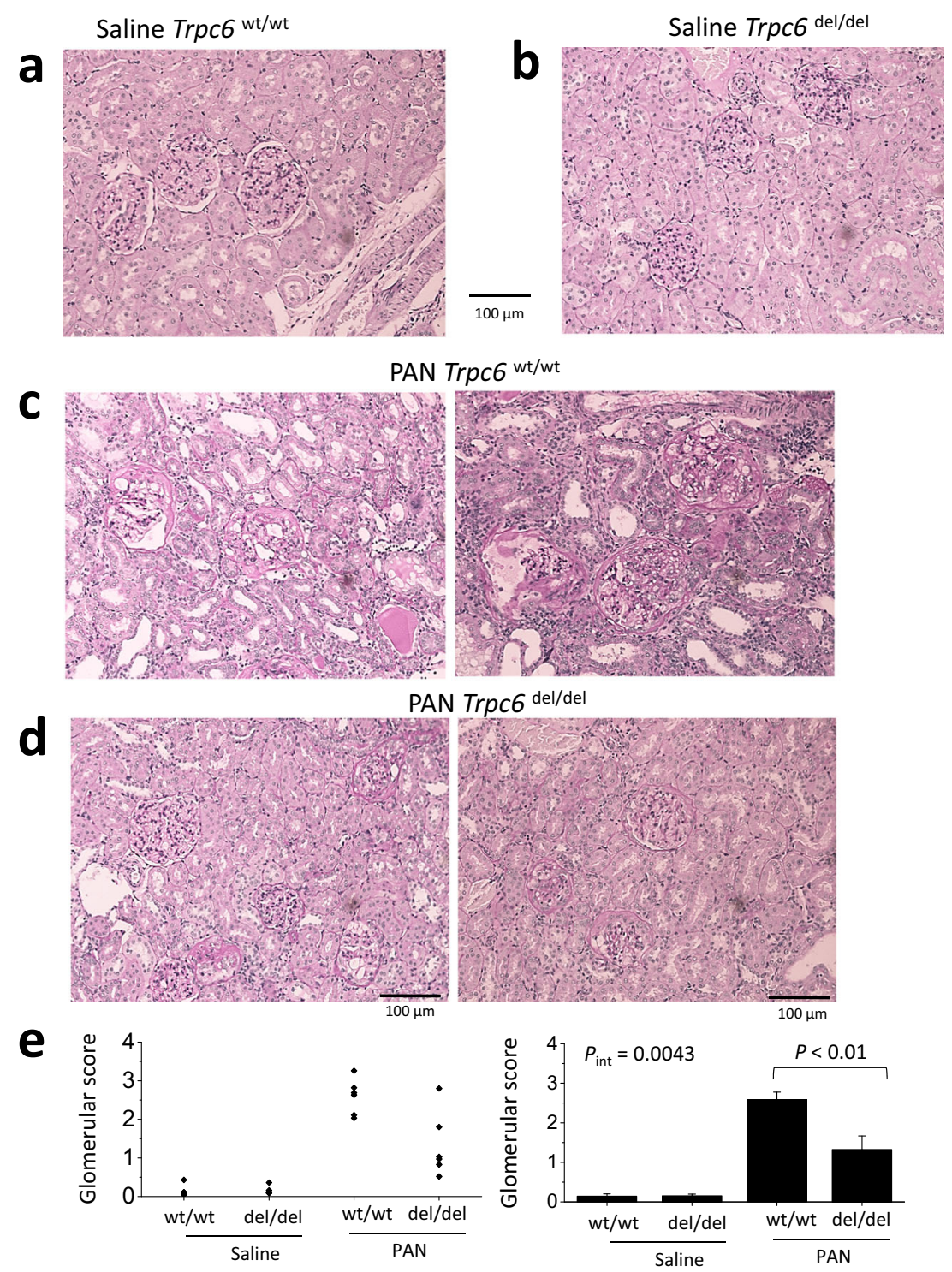

Fig. 5 Histological analysis showing protective effect of Trpc6 exon 2 deletion during chronic PAN nephrosis. PAS-stained sections were prepared after the animals in Fig. 3 were sacrificed. The deletion has no effect on renal histology in saline-treated rats $(\mathbf{a}, \mathbf{b})$. By contrast, there is severe kidney disease in $\operatorname{Trp} c 6^{\mathrm{wt} / \mathrm{wt}}$ rats that received chronic PAN (c). Nearly all of the glomeruli in these animals showed at least some glomerulosclerosis and many were completely collapsed. There were also frequent protein casts within tubules, as well as tubular atrophy and marked interstitial hypercellularity. $\mathbf{d}$ There were still indications of kidney disease in $\operatorname{Trpc} 6^{\mathrm{del} / \mathrm{del}}$ rats that received chronic PAN, but they were markedly less severe. e Mean glomerular score (GS) calculated in a blind manner from PAS-stained sections from each group, with scatter plot showing results from individual animals (left) and bar graph showing

group mean \pm SEM (right). A GS of 0 was assigned to normal glomeruli, one was assigned to glomeruli with mesangial expansion, two was assigned to glomeruli in which sclerosis encompassed less than $50 \%$ of the glomerulus, three was assigned to glomeruli with lesions that encompassed $50-75 \%$ of the glomerulus, and four was assigned to glomeruli with lesions encompassing more than $75 \%$ of the glomerulus, including fully collapsed glomeruli. For each animal, GS was evaluated in 25-50 glomeruli and averaged to obtain a mean value for that animal. Statistical analysis was carried out on the mean values from each group of animals, with $N=6$ rats in each of the four groups. We observed reduced glomerulosclerosis in five out of $\operatorname{six} \operatorname{Trpc} \sigma^{\mathrm{del} / \mathrm{del}}$ rats. This effect was significant by two-way ANOVA and post hoc test

this behavior is not captured in barrier-and-well models that recapitulate other complex features of monovalent and divalent cation permeation through TRPC6 [38]. The shape of the $\mathrm{I}-\mathrm{V}$ curve, beyond some degree of outward rectification at positive membrane potentials, should not be used as a criterion for determining if a particular current is flowing through
TRPC6. However, pharmacological criteria (e.g., inhibition by SAR7334) and molecular criteria such as effects of knockdown [20] or knockout [36, 37], or empty vector controls in heterologous expression systems, are more definitive. In this regard, ATP-activated currents in podocytes are also eliminated after TRPC6 knockdown [21]. 
Fig. 6 Kidney fibrosis in chronic PAN nephropathy is reduced in $\operatorname{Trpc} \sigma^{\mathrm{del} / \mathrm{del}}$ rats. a Immunoblot analysis of $\alpha$-SMA abundance of renal cortex indicates that fibrosis in PAN-treated $\operatorname{Trp} c 6^{\mathrm{wt} / \mathrm{wt}}$ rats is more severe than in $\operatorname{Trpc} \sigma^{\mathrm{del} / \mathrm{del}} . \mathbf{b}$ Masson's trichrome staining showing that fibrosis extends to tubulointerstitial areas during chronic PAN nephrosis
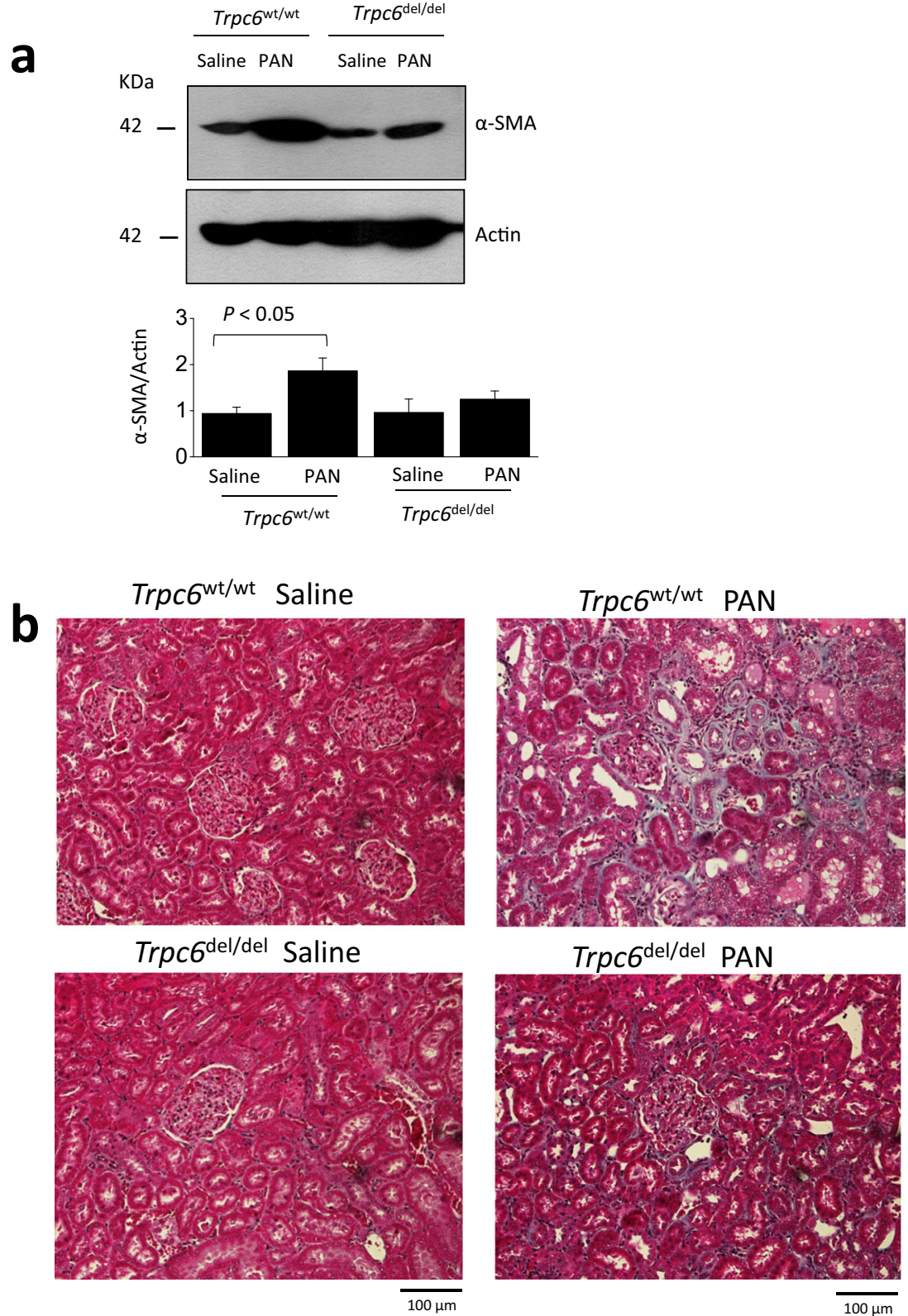

The core observation in this study is that $\operatorname{Trpc} \sigma^{\mathrm{del} / \mathrm{del}}$ rats had less severe kidney disease than $\operatorname{Trpc} 6^{\mathrm{wt} / \mathrm{wt}}$ controls during the chronic phase when FSGS lesions are present. By contrast, we did not see a protective effect during the acute phase of PAN nephrosis. The acute stage of PAN nephrosis is caused by severe oxidative stress resulting from the metabolism of PAN within podocytes, and it bears noting that the lesions typical of FSGS are not present during the acute stage, even though albuminuria is severe $[1,25,26]$.

The effect of the deletion in $\operatorname{Tr} p c 6^{\mathrm{del} / \mathrm{del}}$ in rats, as in $\operatorname{Trpc} \sigma^{\prime}$ mice studied previously, is probably global. Therefore, there is no reason to attribute all of the protective effects to changes the TRPC6 channels in podocytes, because these channels are expressed in other cell types, including glomerular mesangial cells $[11,39,40]$. Indeed, it is possible that a portion of the protective effects observed in $\operatorname{Trpc} \sigma^{\mathrm{del} / \mathrm{del}}$ rats reflects at least mild immunosuppression, as is seen in reduced inflammation associated with airway allergic responses in $\operatorname{Trpc}^{-1}$ mice [41]. TRPC6 channels contribute to $\mathrm{Ca}^{2+}$ responses in macrophages [37], T cells [42], and neutrophils [43] and may also play a role in allowing trans-epithelial migration of leukocytes [44, 45]. TRPC6 channels also contribute to fibroblast activation in kidney following unilateral ureteral obstruction in mice [46, 47]. This could explain in part why the reduction of fibrosis in our model was particularly marked. We observed reduced numbers of CD68positive monocytes and/or macrophages within the glomeruli of PAN-treated Trpc $6^{\mathrm{del} / \mathrm{del}}$ rats, which might occur 
Fig. 7 Trpc6 exon 2 deletion reduces infiltration of CD68expressing cells into glomeruli of PAN-treated animals. a Examples of immunohistochemistry using the monoclonal antibody ED-1, which is directed against CD68, a marker for macrophages and monocytes of myeloid lineage. Inset in lower right panel is shown at higher magnification in $\mathbf{b}$. $\mathbf{c}$ Mean \pm SEM of the average number of ED-1 stained cells per glomerular cross section in each animal ( $N=6$ rats per group). It should be noted however that we did not make serial sections through entire glomeruli. Cells were counted by an observer blind to the nature of the treatment groups

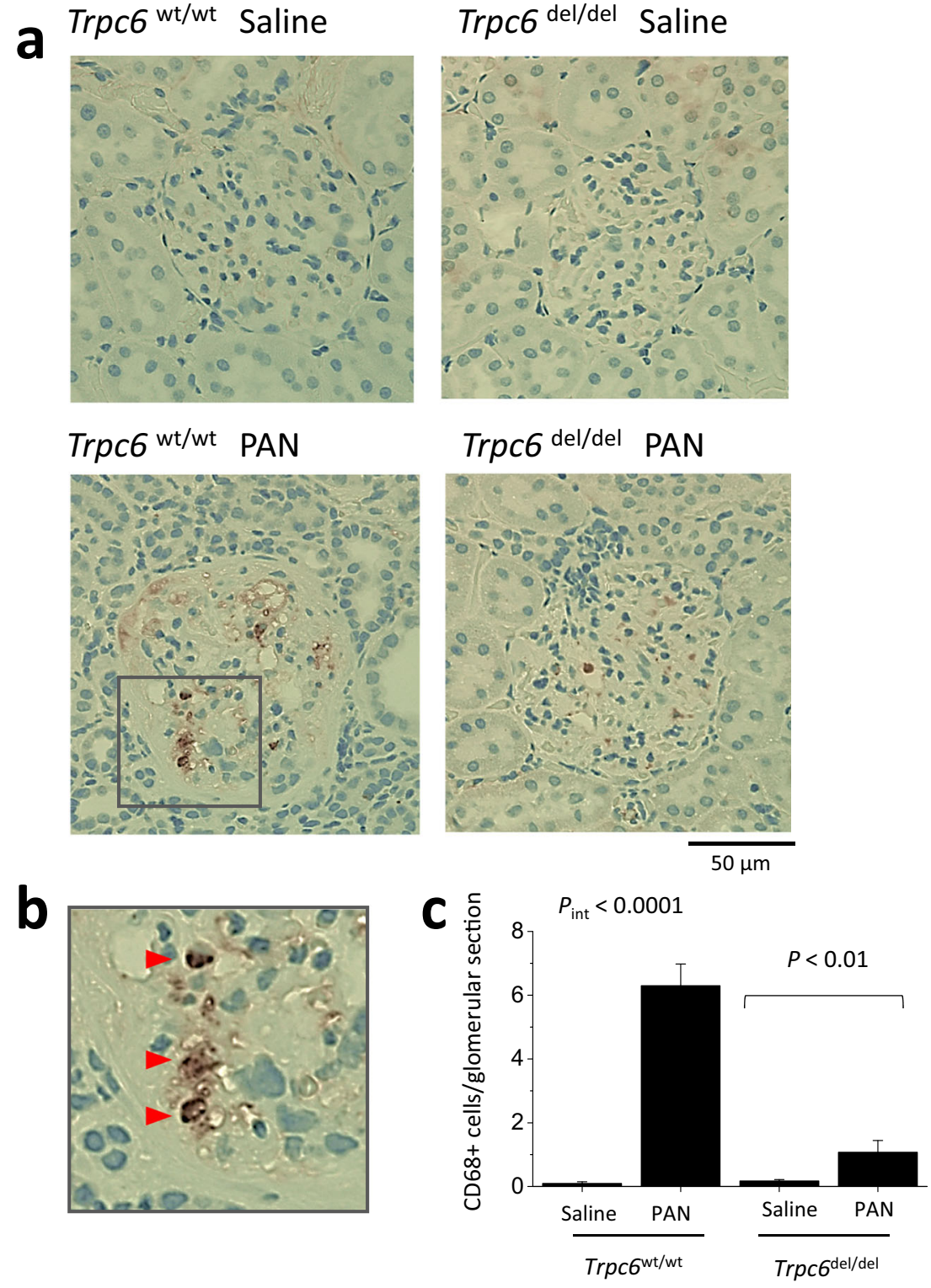

if TRPC6 was required for their full activation, migration, or secretion of immune modulators.

While we cannot exclude a role for TRPC6 in immunomodulation in PAN nephrosis, FSGS is generally considered to be a podocyte disease, and there is a report that podocyte-specific over-expression of TRPC6 results in glomerular disease in mice [16]. In the rat model studied here, following a loss of a threshold number of podocytes during the acute phase of PAN nephrosis [1], podocytes on the remaining capillary tufts are subjected to increased hydrostatic pressures that can drive their detachment $[2,3,26]$. We have previously observed that TRPC6 becomes active in response to mechanical stimuli in rat podocytes $[13,20]$. It is possible that shear and expansile forces associated with glomerular hyperfiltration lead to sustained and excessive activation of TRPC6 in glomerular cells resulting $\mathrm{Ca}^{2+}$ overload in foot processes and changes in gene expression, including upregulation of TRPC6 itself [48]. While such changes may be adaptive in the short term, it is possible that sustained activation of TRPC6 eventually increases the loss of podocytes.

The protection seen in $\operatorname{Trpc} \sigma^{\mathrm{del} / \mathrm{del}}$ rats, while statistically and biologically robust, was not complete in the later chronic phase of PAN nephrosis (60 days). Clearly, there are multiple processes involved in the pathogenesis of chronic kidney disease and it may be unrealistic to expect complete protection to result from any single manipulation. It is possible that the effect would be more complete if other TRPC channels, such as TRPC5 and/or TRPC3, were also suppressed. TRPC5 is expressed in podocytes $[13,49,50]$ and has been suggested to play a role in nephrotic syndromes $[51,52]$ and can be 
Fig. 8 Trpc6 exon 2 deletion reduces ultrastructural changes evoked by chronic PAN. These transmission electron micrographs were prepared from the same animals of Fig. 3 after sacrifice. a In $\operatorname{Trpc} 6^{\mathrm{wt} / \mathrm{wt}}$ animals, chronic PAN nephrosis was associated with extensive foot process effacement and marked thickening and disruption and thickening of glomerular basement membrane (left). Many capillary loops no longer had discernible foot processes. In $\operatorname{Trpc} \sigma^{\mathrm{del} / \mathrm{del}}$ rats, we still observed some effacement and thickening of foot processes. However, ultrastructure was substantially closer to normal (right). b Trpc6 exon 2 deletion has no effect on glomerular ultrastructure in saline-treated rats. c

Quantification of the effects of exon 2 deletion on mean foot process width (FPW) and GBM thickness (GBMW) in saline- and PAN-treated animals

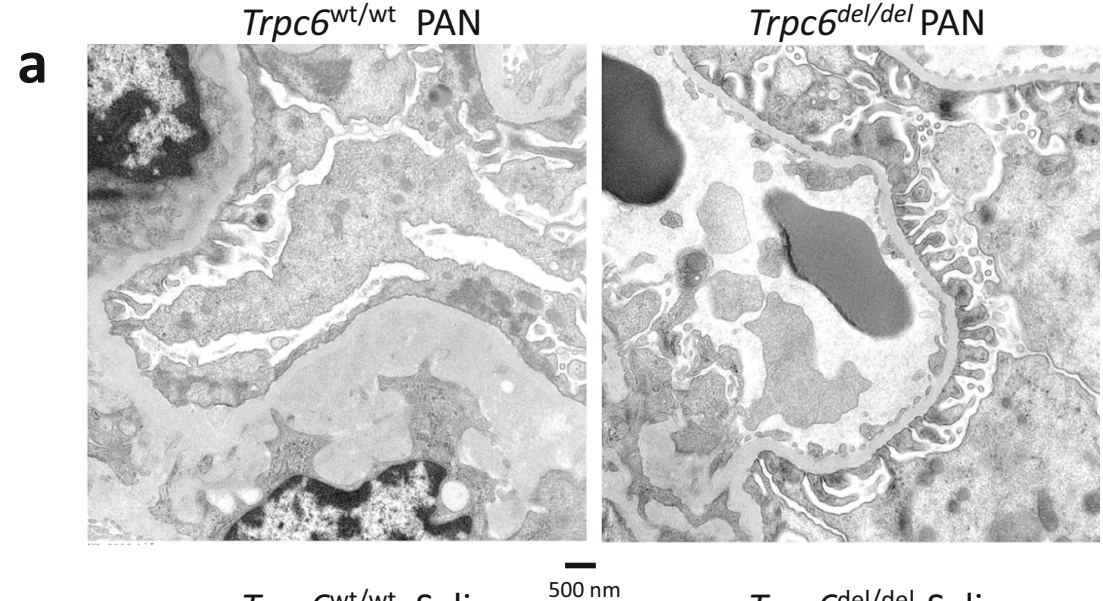

b
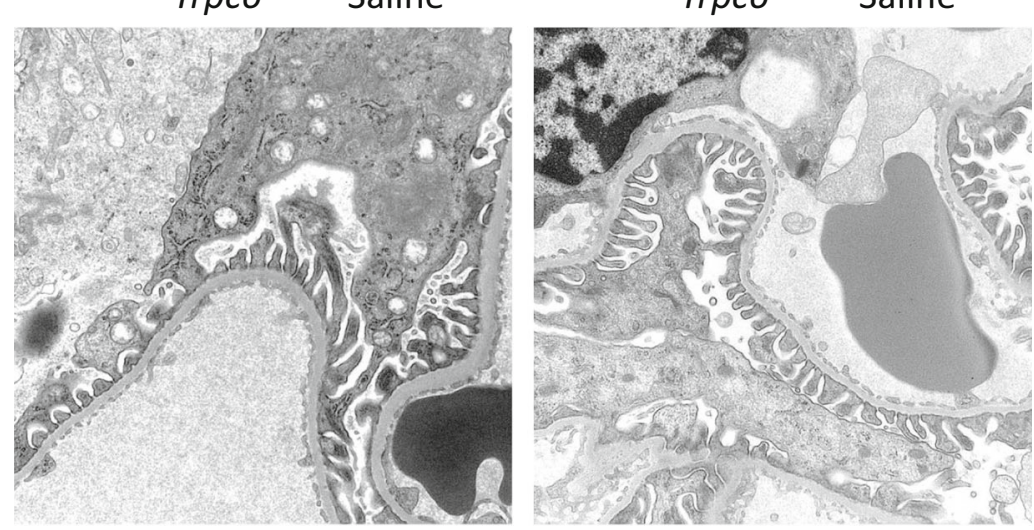

C

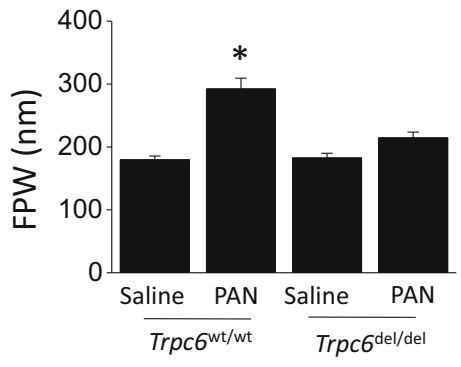

mobilized to surface under in vitro conditions designed to mimic severe primary FSGS [13]. While we observed that TRPC5 abundance was not altered in the chronic PAN model or in $\operatorname{Trpc} 6^{\text {del/del }}$ rats, it is possible that TRPC5 is more important in other forms of kidney disease or in other experimental models. TRPC3 was more abundant in renal cortex of $\operatorname{Trpc} 6^{\mathrm{del} / \mathrm{del}}$ animals compared to saline-treated $\operatorname{Tr} p c 6^{\mathrm{wt} / \mathrm{wt}}$ littermates. Chronic PAN nephrosis also led to an increase of TRPC 3 abundance in $\operatorname{Trpc} 6^{\mathrm{wt} / \mathrm{wt}}$ animals. However, renal cortical TRPC3 did not increase further following PAN treatment in $\operatorname{Trpc} 6^{\text {del/del }}$ rats (Supplemental Fig. 5).

In summary, we have CRISPR/Cas9 methods to delete a portion of the Trpc6 gene in rats, resulting in a strongly hypomorphic allele that is missing portions of the channel thought to be required for assembly, and which appears to be non-functional. Animals homozygous for that deletion had less kidney disease in the chronic PAN nephrosis model as assessed by multiple measures. These observations have been made in a different species than has been used in previous studies on TRPC6 and in a model that produces severe disease that closely resembles that seen in humans. These observations support therapeutic strategies based on inhibition of TRPC 6 channels or targeting the pathways that lead to their dysregulation.

Acknowledgements We are grateful to Mr. Kenneth Dunner, Jr. B.A., A.B., of the M.D. Anderson Cancer Center in Houston, TX for carrying out electron microscopy.

Funding information This work was supported by National Institutes of Health grant R01-DK104708. The High-Resolution Electron Microscopy Facility at the M. D. Anderson Cancer Center in Houston, TX is supported by National Institutes of Health grant P30-CA-016672. 


\section{Compliance with ethical standards}

Conflict of interest The authors have no financial interests to declare.

Open Access This article is distributed under the terms of the Creative Commons Attribution 4.0 International License (http:// creativecommons.org/licenses/by/4.0/), which permits unrestricted use, distribution, and reproduction in any medium, provided you give appropriate credit to the original author(s) and the source, provide a link to the Creative Commons license, and indicate if changes were made.

\section{References}

1. Kim YH, Goyal M, Kurnit D, Wharram B, Wiggins J, Holzman L, Kershaw D, Wiggins R (2001) Podocyte depletion and glomerulosclerosis have a direct relationship in the PAN-treated rat. Kidney Int 60:957-968

2. LeHir M, Kriz W (2007) New insights into structural patterns encountered in glomerulosclerosis. Curr Opin Nephrol Hypertens 16: 184-191

3. Kriz W, Lemley KV (2017) Mechanical challenges to the glomerular filtration barrier: adaptations and pathway to sclerosis. Pediatr Nephrol 32:405-417.4

4. McCarthy ET, Sharma M, Savin VJ (2010) Circulating permeability factors in idiopathic nephrotic syndrome and focal segmental glomerulosclerosis. Clin J Am Soc Nephrol 5:2115-2121

5. Davin JC (2016) The glomerular permeability factors in idiopathic nephrotic syndrome. Pediatr Nephrol 31:207-215

6. Winn MP, Conlon PJ, Lynn KL, Farrington MK, Creazzo T, Hawkins AF, Daskalakis N, Kwan SY, Ebersviller S, Burchette JL, Pericak-Vance MA, Howell DN, Vance JM, Rosenberg PB (2005) A mutation in the TRPC6 cation channel causes familial focal segmental glomerulosclerosis. Science 308:1801-1804

7. Reiser J, Polu KR, Möller CC, Kenlan P, Altintas MM, Wei C, Faul C, Herbert S, Villegas I, Avila-Casado C, McGee M, Sugimoto H, Brown D, Kalluri R, Mundel P, Smith PL, Clapham DE, Pollak MR (2005) TRPC6 is a glomerular slit diaphragm-associated channel required for normal renal function. Nat Genet 37:739-744

8. Heeringa SF, Möller CC, Du J, Yue L, Hinkes B, Chernin G, Vlangos CN, Hoyer PF, Reiser J, Hildebrandt F (2009) A novel TRPC6 mutation that causes childhood FSGS. PLoS One 4:e7771

9. Riehle M, Büscher AK, Gohlke BO, Kaßmann M, Kolatsi-Joannou M, Bräsen JH, Nagel M, Becker JU, Winyard P, Hoyer PF, Preissner R, Krautwurst D, Gollasch M, Weber S, Harteneck C (2016) TRPC6 G757D loss-of-function mutation associates with FSGS. J Am Soc Nephrol 27:2771-2783

10. Sadowski CE, Lovric S, Ashraf S, Pabst WL, Gee HY, Kohl S, Engelmann S, Vega-Warner V, Fang H, Halbritter J, Somers MJ, Tan W, Shril S, Fessi I, Lifton RP, Bockenhauer D, el-Desoky S, Kari JA, Zenker M, Kemper MJ, Mueller D, Fathy HM, Soliman NA, the SRNS Study Group, Hildebrandt F (2015) A single-gene cause in $29.5 \%$ of cases of steroid-resistant nephrotic syndrome. $\mathrm{J}$ Am Soc Nephrol 26:1279-1289

11. Bouron A, Chauvet S, Dryer SE, Rosado JA (2016) Second messenger-operated calcium entry through TRPC6. Adv Exp Med Biol 898:201-249

12. Möller CC, Wei C, Altintas MM, Li J, Greka A, Ohse T, Pippin JW, Rastaldi MP, Wawersik S, Schiavi S et al (2007) Induction of TRPC6 channel in acquired forms of proteinuric kidney disease. J Am Soc Nephrol 18:29-36

13. Kim EY, Roshanravan H, Dryer SE (2017) Changes in podocyte TRPC channels evoked by plasma and sera from patients with recurrent FSGS and by putative glomerular permeability factors. Biochim Biophys Acta 1863:2342-2354

14. Eckel J, Lavin PJ, Finch EA, Mukerji N, Burch J, Gbadegesin R, Wu G, Bowling B, Byrd A, Hall G et al (2011) TRPC6 enhances angiotensin II-induced albuminuria. J Am Soc Nephrol 22(3):526535

15. Wang L, Jirka G, Rosenberg PB, Buckley AF, Gomez JA, Fields TA, Winn MP, Spurney RF (2015) Gq signaling causes glomerular injury by activating TRPC6. J Clin Invest 125:1913-1926

16. Krall P, Canales CP, Kairath P, Carmona-Mora P, Molina J, Carpio JD, Ruiz P, Mezzano SA, Li J, Wei C, Reiser J, Young JI, Walz K (2010) Podocyte-specific overexpression of wild type or mutant trpc6 in mice is sufficient to cause glomerular disease. PLoS One 5:e12859

17. Susztak K, Bitzer M, Meyer TW, Hostetter TH (2008) Animal models of renal disease. Kidney Int 73:536-538

18. Mou H, Smith JL, Peng L, Yin H, Moore J, Zhang XO, Song CQ, Sheel A, Wu Q, Ozata DM, Li Y, Anderson DG, Emerson CP, Sontheimer EJ, Moore MJ, Weng Z, Xue W (2017) CRISPR/ Cas9-mediated genome editing induces exon skipping by alternative splicing or exon deletion. Genome Biol 18:108

19. Kapahnke M, Banning A, Tikkanen R (2016) Random splicing of several exons caused by a single base change in the target exon of CRISPR/Cas9 mediated gene knockout. Cell 5:45

20. Anderson M, Kim EY, Hagmann H, Benzing T, Dryer SE (2013) Opposing effects of podocin on the gating of podocyte TRPC6 channels evoked by membrane stretch or diacylglycerol. Am J Physiol Cell Physiol 305:C276-C289

21. Roshanravan H, Dryer SE (2014) ATP acting through P2Y receptors causes activation of podocyte TRPC6 channels: role of podocin and reactive oxygen species. Am J Physiol Renal Physiol 306: F1088-F1097

22. Maier T, Follmann M, Hessler G, Kleemann HW, Hachtel S, Fuchs B, Weissmann N, Linz W, Schmidt T, Löhn M, Schroeter K, Wang L, Rütten H, Strübing C (2015) Discovery and pharmacological characterization of a novel potent inhibitor of diacylglycerolsensitive TRPC cation channels. Br J Pharmacol 172:3650-3660

23. Roshanravan H, Kim EY, Dryer SE (2016) NMDA receptors as potential therapeutic targets in diabetic nephropathy: increased renal NMDA receptor subunit expression in Akita mice and reduced nephropathy following sustained treatment with memantine or MK801. Diabetes 65(10):3139-3150

24. Gundersen HJ, Seefeldt T, Osterby R (1980) Glomerular epithelial foot processes in normal man and rats. Distribution of true width and its intra- and inter-individual variation. Cell Tissue Res 205: $147-155$

25. Cahill MM, Ryan GB, Bertram JF (1996) Biphasic glomerular hypertrophy in rats administered puromycin aminonucleoside. Kidney Int 50:768-775

26. Anderson S, Diamond JR, Karnovsky MJ, Brenner BM (1988) Mechanisms underlying transition from acute glomerular injury to late glomerular sclerosis in a rat model of nephrotic syndrome. J Clin Invest 82:1757-1768

27. Lepage PK, Lussier MP, Barajas-Martinez H, Bousquet SM, Blanchard AP, Francoeur N, Dumaine R, Boulay G (2006) Identification of two domains involved in the assembly of transient receptor potential canonical channels. J Biol Chem 281:3035630364

28. Lepage PK, Lussier MP, McDuff FO, Lavigne P, Boulay G (2009) The self-association of two N-terminal interaction domains plays an important role in the tetramerization of TRPC4. Cell Calcium 45: 251-259

29. Schindl R, Frischauf I, Kahr H, Fritsch R, Krenn M, Derndl A, Vales E, Muik M, Derler I, Groschner K, Romanin C (2008) The first ankyrin-like repeat is the minimum indispensable key structure 
for functional assembly of homo- and heteromeric TRPC4/TRPC5 channels. Cell Calcium 43:260-269

30. Liu Y, Echtermeyer F, Thilo F, Theilmeier G, Schmidt A, Schülein R, Jensen BL, Loddenkemper C, Jankowski V, Marcussen N, Gollasch M, Arendshorst WJ, Tepel M (2012) The proteoglycan syndecan 4 regulates transient receptor potential canonical 6 channels via RhoA/Rho-associated protein kinase signaling. Arterioscler Thromb Vasc Biol 32:378-385

31. Inoue R, Okada $\mathrm{T}$, Onoue $\mathrm{H}$, Hara $\mathrm{Y}$, Shimizu $\mathrm{S}$, Naitoh $\mathrm{S}$, Ito $\mathrm{Y}$, Mori Y (2001) The transient receptor potential protein homologue TRP6 is the essential component of vascular alpha ${ }_{1}$-adrenoceptoractivated $\mathrm{Ca}^{2+}$-permeable cation channel. Circ Res 88:325-332

32. Leuner K, Heiser JH, Derksen S, Mladenov MI, Fehske CJ, Schubert R, Gollasch M, Schneider G, Harteneck C, Chatterjee SS, Müller WE (2010) Simple 2,4-diacylphloroglucinols as classic transient receptor potential-6 activators - identification of a novel pharmacophore. Mol Pharmacol 77:368-377

33. Shen B, Kwan HY, Ma X, Wong CO, Du J, Huang Y, Yao X (2011) cAMP activates TRPC6 channels via the phosphatidylinositol 3kinase (PI3K)-protein kinase $\mathrm{B}(\mathrm{PKB})$-mitogen-activated protein kinase kinase (MEK)-ERK1/2 signaling pathway. J Biol Chem 286:19439-19445

34. Dietrich A, Mederos Y, Schnitzler M, Gollasch M, Gross V, Storch U, Dubrovska G, Obst M, Yildirim E, Salanova B, Kalwa H, Essin K, Pinkenburg O, Luft FC, Gudermann T, Birnbaumer L (2005) Increased vascular smooth muscle contractility in TRPC6-/- mice. Mol Cell Biol 25:6980-6989

35. Weissmann N, Dietrich A, Fuchs B, Kalwa H, Ay M, Dumitrascu R, Olschewski A, Storch U, Mederos y Schnitzler M, Ghofrani HA, Schermuly RT, Pinkenburg O, Seeger W, Grimminger F, Gudermann T (2006) Classical transient receptor potential channel 6 (TRPC6) is essential for hypoxic pulmonary vasoconstriction and alveolar gas exchange. Proc Natl Acad Sci U S A 103:1909319098

36. Xie J, Cha SK, An SW, Kuro-o M, Birnbaumer L, Huang CL (2012) Cardioprotection by Klotho through downregulation of TRPC6 channels in the mouse heart. Nat Commun 3:1238

37. Riazanski V, Gabdoulkhakova AG, Boynton LS, Eguchi RR, Deriy LV, Hogarth DK, Loaëc N, Oumata N, Galons H, Brown ME, Shevchenko P, Gallan AJ, Yoo SG, Naren AP, Villereal ML, Beacham DW, Bindokas VP, Birnbaumer L, Meijer L, Nelson DJ (2015) TRPC6 channel translocation into phagosomal membrane augments phagosomal function. Proc Natl Acad Sci U S A 112: E6486-E6495

38. Estacion M, Sinkins WG, Jones SW, Applegate MA, Schilling WP (2006) Human TRPC6 expressed in HEK 293 cells forms nonselective cation channels with limited $\mathrm{Ca} 2+$ permeability. J Physiol 572:359-377

39. Dryer SE, Reiser J (2010) TRPC6 channels and their binding partners in podocytes: role in glomerular filtration and pathophysiology. Am J Physiol Renal Physiol 299:F689-F701

40. Sours S, Du J, Chu S, Ding M, Zhou XJ, Ma R (2006) Expression of canonical transient receptor potential (TRPC) proteins in human glomerular mesangial cells. Am J Physiol Renal Physiol 290: F1507-F1515
41. Sel S, Rost BR, Yildirim AO, Sel B, Kalwa H, Fehrenbach H, Renz H, Gudermann T, Dietrich A (2008) Loss of classical transient receptor potential 6 channel reduces allergic airway response. Clin Exp Allergy 38:1548-1558

42. Carrillo C, Hichami A, Andreoletti P, Cherkaoui-Malki M, del Mar Cavia M, Abdoul-Azize S, Alonso-Torre SR, Khan NA (2012) Diacylglycerol-containing oleic acid induces increases in $\left[\mathrm{Ca}^{2+}\right]_{i}$ via TRPC3/6 channels in human T-cells. Biochim Biophys Acta 1821:618-626

43. Lindemann O, Umlauf D, Frank S, Schimmelpfennig S, Bertrand J, Pap T, Hanley PJ, Fabian A, Dietrich A, Schwab A (2013) TRPC6 regulates CXCR2-mediated chemotaxis of murine neutrophils. J Immunol 190:5496-5505

44. Tauseef M, Knezevic N, Chava KR, Smith M, Sukriti S, Gianaris N, Obukhov AG, Vogel SM, Schraufnagel DE, Dietrich A, Birnbaumer L, Malik AB, Mehta D (2012) TLR4 activation of TRPC6-dependent calcium signaling mediates endotoxin-induced lung vascular permeability and inflammation. J Exp Med 209: 1953-1968

45. Weber EW, Han F, Tauseef M, Birnbaumer L, Mehta D, Muller WA (2015) TRPC6 is the endothelial calcium channel that regulates leukocyte transendothelial migration during the inflammatory response. J Exp Med 212:1883-1899

46. Saliba Y, Karam R, Smayra V, Aftimos G, Abramowitz J, Birnbaumer L, Farès N (2015) Evidence of a role for fibroblast transient receptor potential canonical $3 \mathrm{Ca}^{2+}$ channel in renal fibrosis. J Am Soc Nephrol 26:1855-1876

47. Wu YL, Xie J, An SW, Oliver N, Barrezueta NX, Lin MH, Birnbaumer L, Huang CL (2017) Inhibition of TRPC6 channels ameliorates renal fibrosis and contributes to renal protection by soluble klotho. Kidney Int 91:830-841

48. Nijenhuis T, Sloan AJ, Hoenderop JG, Flesche J, van Goor H, Kistler AD, Bakker M, Bindels RJ, de Boer RA et al (2011) Angiotensin II contributes to podocyte injury by increasing TRPC6 expression via an NFAT-mediated positive feedback signaling pathway. Am J Pathol 179:1719-1732

49. Tian D, Jacobo SM, Billing D, Rozkalne A, Gage SD, Anagnostou T, Pavenstädt H, Hsu HH, Schlöndorff J, Ramos A, Greka A (2010) Antagonistic regulation of actin dynamics and cell motility by TRPC5 and TRPC6 channels. Sci Signal 3:ra77

50. Kim EY, Anderson M, Dryer SE (2012) Insulin increases surface expression of TRPC6 channels in podocytes: role of NADPH oxidases and reactive oxygen species. Am J Physiol Renal Physiol 302:F298-F307

51. Schaldecker T, Kim S, Tarabanis C, Tian D, Hakroush S, Castonguay P, Ahn W, Wallentin H, Heid H, Hopkins CR, Lindsley CW, Riccio A, Buvall L, Weins A, Greka A (2013) Inhibition of the TRPC5 ion channel protects the kidney filter. J Clin Invest 123:5298-5309

52. Zhou Y, Castonguay P, Sidhom EH, Clark AR, Dvela-Levitt M, Kim S, Sieber J, Wieder N, Jung JY, Andreeva S et al (2017) A small-molecule inhibitor of TRPC5 ion channels suppresses progressive kidney disease in animal models. Science 358:1322-1336 